\title{
Relationship between Vegetables and Fruit Consumption Habits, Nutrition Intake, Physical Activity, and Family Support with Adolescent Nutritional Status
}

\author{
Nanda Rizkha Heratama ${ }^{1^{*}}$, Kusnandar ${ }^{2}$, Suminah ${ }^{3}$ \\ 1,2,3 Universitas Sebelas Maret, Indonesia \\ *Email: nandafayzaa@gmail.com
}

\begin{abstract}
Adolescents nutritional status is one of the major challenges for health workers and society, which is caused by their excessive intake of food, but lack of fiber intake and lack of physical activity. This research is to know how relationship between vegetables and fruit habits, nutrition and family support with adolescent nutritional status. This research design used was cross sectional, where research is conducted one-time to find relationships between the independent variable and the dependent variable. Its samples consisted of 340 adolescents in Pangkalpinang city. Subjects were screened by using google form first, data collection is done directly with the help of enumerators. The results of statistical tests showed that the habit of consuming vegetables $(p=0.005)$ and physical activity $(p=0.016)$ were the variables that had the most influence on adolescent nutritional status. Adolescents who often consume vegetables and have a minimum physical activity of 600METs / day have the opportunity to have a good nutritional status.
\end{abstract}

Keywords: Family Support, Nutrition, Nutritional Status.

\section{A. INTRODUCTION}

Obesity is one of the determinants of mortality and morbidity. World Health Organization (2016) stated that overweight and obesity are ranked in the top fifth of the risk global mortality. Atleast 2.8 million people adults are die every year due to overweigth and obesity (Harista, 2012). Based on the data from the 2013 Basic Health Research (Riskesdas), the prevalence of adolescent obesity in Indonesia according to the age group of $16-18$ years was $7.3 \%$. In 2018, the prevalence of overweight adolescents was $13.5 \%$, with a fat nutritional status of $9.5 \%$ and obesity of $4 \%$ (Riskesdas, 2013). Besides, Indonesia is noted to have an inadequate prevalence of vegetable and fruit intake as well. Indonesia consumption of fruit and vegetables in the $15-19$ age group is only $3.6 \%$ and only $2.9 \%$ in Bangka Belitung. Bangka Belitung has the second highest prevalence of adolescent obesity by province after DKI Jakarta, which is $6.3 \%$ and fat is $9.1 \%$. The highest results of research on adolescents was in Pangkalpinang City, there were $6 \%$ of adolescents who were overweight (Emilia, 2016).

Nutritional status is influenced by other factors such as sedentary behavior and low physical activity, increased consumption of high-calorie foods and highsugar drinks (Hume, et al., 2009). Children and adolescents who have a low level of strenuous physical activity are more at risk of becoming overweight or obese and 
have a high risk of a larger waist circumference (Ortega et al., 2007).

Family support plays an important role in shaping adolescent diet behavior and physical activity. Family support is associated with increased physical activity (Wang \& Lobstein, 2006). Family support also contributes to improving normal nutritional status in adolescents (Hume, et al., 2009).

Considering those issues, it is important to research regarding the relationship between vegetable and fruit consumption, nutrient intake, physical activity, as well as family support with nutritional status in adolescents. The objective of this research is to analyze the relationship between fruit and vegetable consumption habits and substance intake nutrition, physical activity and family support with the nutritional status of adolescents aged 16-18 years.

\section{B. METHOD}

This research used a cross sectional design with analytic observasional. Proportional random sampling was used to determine samples. They consisted of 340 adolescents in Pangkal Pinang City. Subjects were screened using google form first, data collection is carried out directly by door to door with the help of enumerators.

The inclusion criteria of the samples included the following: the adolescents were aged 16-18 years, living with parents, adolescents have no history of illness for the last 3 months and they were willing to be respondents. Meanwhile, the exclusion criteria were as follows: adolescents who are taking drugs can affect height and weight, they did not participate in all research activities, they suffered from diseases that required a certain diet (diabetes, kidney, heart disease, cancer, hypertension) and who are on a diet to lose or gain weight.

The dependent variables in this study was adolescents nutrition status. Respondent who met the inclusion criteria were given an explanation of the objectives and research procedures and filled out an informed consent via e-form. To collect family support data using a family support questionnaire. Nutritional intake and consumption habits of vegetables and fruit using recall 2x24 hours without succession and the FFsQ questionnaire. Retrieve physical activity data using a physical activity questionnaire.

This research protocol was approved by the Ethics Committee of Universitas Sebelas Maret Surakarta through Decision Letter Number 072/UN27.06.6.1/KEPK/EC/2020. In this study, the data were obtained and analyzed by using SPSS Version 16. The data of the research were then exposed to Chi Square Test and the Logistic Regression test to investigate the relationship between vegetables and fruit consumption, nutrition intake and family support with adolescents nutritional status. 


\section{RESULT AND DISCUSSION}

\section{Characteristics of Research Subjects}

The subjects studied were 340 adolescents. The characteristics of the research subjects can be seenin Table 1 .

Table 1 Characteristics of Research Subjects

\begin{tabular}{|l|r|r|}
\hline \multicolumn{1}{|c|}{ Characteristics } & n & \% \\
\hline Gender & 105 & 30.9 \\
- Male & 235 & 69.1 \\
- Female & & \\
\hline Age & 307 & 90.3 \\
- 16 years & 21 & 6.2 \\
- 17 years & 12 & 3.5 \\
- 18 years & & \\
\hline Availability of Vegetables & 72 & 21.1 \\
- Available every day & 105 & 30.9 \\
- Available 3-6day/week & 163 & 48.0 \\
- Not available everyday & & \\
\hline Availability of Fruits & 178 & 52.4 \\
- Available every day & 47 & 13.8 \\
- Available 3-6day/week & 115 & 33.8 \\
\hline
\end{tabular}

Adolescents show that $69.1 \%$ of the respondents were females, and mostly the subjects $(90.3 \%)$ were aged 16 years old. The availability of vegetables from the research respondents, namely as many as 163 respondents $(48.0 \%)$ stated that there were no vegetables available everyday. On the other hand, most of the respondents stated that fruits was available every day (52.4\%).

Frequency Distribution of Nutritional Status Variables, Vegetables and Fruits Consumption Habits, Nutrition Intake, Physical Activity and Family Support

Table 2 reveals that the majority of adolescents in high school equivalents in Pangkalpinang city are well-nourished (61.8\%) and have frequent consumption of vegetable and fruit ( $\geq 5$ times/week) of $66.5 \%$ and $70.9 \%$. Most of the respondents had an adequate intake of carbohydrates (91.8\%), but almost all respondents had insufficient intake of fat $(74.4 \%)$, protein $(97.4 \%)$ and fibre $(97.4 \%), 154$ adolescents have low physical activity (45.3\%) and low family support $(82.1 \%)$. 
Table 2 Frequency Distribution of Nutritional Status Variables, Vegetable and FruitConsumption Habits, Nutrient Intake, Physical Activity and Family Support

\begin{tabular}{|c|c|c|c|}
\hline Variable & Category & Number (n) & Percentage (\%) \\
\hline $\begin{array}{l}\text { Nutritional Status (IMT/U): } \\
\text { Z score }>1 \text { SD } \\
\text { Z score }-2 \text { SD s/d 1 SD } \\
\text { Z score }<-2 \text { SD }\end{array}$ & $\begin{array}{l}\text { Malnutrition } \\
\text { Good Nutrition } \\
\text { Malnutrition }\end{array}$ & $\begin{array}{c}106 \\
210 \\
24\end{array}$ & $\begin{array}{c}31.2 \\
61.8 \\
7.0\end{array}$ \\
\hline $\begin{array}{l}\text { Vegetables Consumption Habits: } \\
\geq 5 \text { times / week } \\
<5 \text { times / week }\end{array}$ & $\begin{array}{l}\text { Often } \\
\text { Rarely }\end{array}$ & $\begin{array}{l}226 \\
114 \\
\end{array}$ & $\begin{array}{l}66.5 \\
33.5 \\
\end{array}$ \\
\hline $\begin{array}{l}\text { Fruits Consumption Habits: } \\
\geq 5 \text { times / week } \\
<5 \text { times / week }\end{array}$ & $\begin{array}{l}\text { Often } \\
\text { Rarely }\end{array}$ & $\begin{array}{c}241 \\
99 \\
\end{array}$ & $\begin{array}{l}70.9 \\
29.1 \\
\end{array}$ \\
\hline $\begin{array}{l}\text { Carbohydrate intake } \\
>80 \% \text { AKG } \\
<80 \% \text { AKG }\end{array}$ & $\begin{array}{c}\text { Sufficient } \\
\text { Low }\end{array}$ & $\begin{array}{c}312 \\
28 \\
\end{array}$ & $\begin{array}{c}91.8 \\
8.2 \\
\end{array}$ \\
\hline $\begin{array}{l}\text { Protein intake } \\
>80 \% \mathrm{AKG} \\
<80 \% \mathrm{AKG}\end{array}$ & $\begin{array}{c}\text { Sufficient } \\
\text { Low }\end{array}$ & $\begin{array}{c}9 \\
331 \\
\end{array}$ & $\begin{array}{c}2.6 \\
97.4 \\
\end{array}$ \\
\hline $\begin{array}{l}\text { Fat intake } \\
>80 \% \mathrm{AKG} \\
<80 \% \mathrm{AKG}\end{array}$ & $\begin{array}{c}\text { Sufficient } \\
\text { Low }\end{array}$ & $\begin{array}{r}87 \\
253 \\
\end{array}$ & $\begin{array}{l}25.6 \\
74.4 \\
\end{array}$ \\
\hline $\begin{array}{l}\text { Fibre intake } \\
>80 \% \mathrm{AKG} \\
<80 \% \mathrm{AKG}\end{array}$ & $\begin{array}{c}\text { Sufficient } \\
\text { Low }\end{array}$ & $\begin{array}{c}9 \\
331 \\
\end{array}$ & $\begin{array}{c}2.6 \\
97.4 \\
\end{array}$ \\
\hline $\begin{array}{l}\text { Physically activity } \\
\text { MET }<600 \text { minutes } \\
\text { MET min } 600 \text { minutes } \\
\text { MET } \geq 1500 \text { minutes }\end{array}$ & $\begin{array}{l}\text { Low } \\
\text { Middle } \\
\text { High }\end{array}$ & $\begin{array}{c}154 \\
152 \\
34\end{array}$ & $\begin{array}{c}45.3 \\
44.7 \\
10\end{array}$ \\
\hline $\begin{array}{l}\text { Family Support } \\
X<\text { Median }(57) \\
X \geq \text { Median(57) }\end{array}$ & $\begin{array}{l}\text { Low } \\
\text { High }\end{array}$ & $\begin{array}{c}279 \\
61\end{array}$ & $\begin{array}{l}82.1 \\
17.9\end{array}$ \\
\hline
\end{tabular}

\section{Analysis Result}

Bivariate analysis was conducted to determine whether there was a relationship between the independent variable consumption habits of vegetables and fruits, nutritional intake, physical activity and family support with the dependent variable nutritional status, using the chi-square test. 
Table 3 Relationship between Variables of Vegetable and Fruit Consumption Habits, NutrientIntake, Physical Activity and Family Support with Nutritional

Status

\begin{tabular}{|c|c|c|c|c|c|c|c|c|}
\hline \multirow{3}{*}{ Variable } & \multicolumn{4}{|c|}{ Nutritional Status } & \multirow{2}{*}{\multicolumn{2}{|c|}{ Total }} & \multirow[t]{3}{*}{ OR } & \multirow[t]{3}{*}{$p$-value } \\
\hline & \multicolumn{2}{|c|}{ Good Nutrition } & \multicolumn{2}{|c|}{ Malnutrition } & & & & \\
\hline & $\mathrm{n}$ & $\%$ & $\mathrm{n}$ & $\%$ & $\mathrm{n}$ & $\%$ & & \\
\hline $\begin{array}{l}\text { Vegetables Consumption Habits } \\
\text { - Often } \\
\text { - Rarely }\end{array}$ & $\begin{array}{c}152 \\
58\end{array}$ & $\begin{array}{l}67.3 \\
50.9\end{array}$ & $\begin{array}{l}74 \\
56\end{array}$ & $\begin{array}{l}32.7 \\
49.1\end{array}$ & $\begin{array}{l}226 \\
114\end{array}$ & $\begin{array}{l}100 \\
100\end{array}$ & 1.938 & 0.005 \\
\hline $\begin{array}{l}\text { Fruits Consumption Habits } \\
\text { - Often } \\
\text { - Rarely }\end{array}$ & $\begin{array}{c}144 \\
66 \\
\end{array}$ & $\begin{array}{l}59.8 \\
66.7 \\
\end{array}$ & $\begin{array}{l}97 \\
33 \\
\end{array}$ & $\begin{array}{l}40.2 \\
33.3 \\
\end{array}$ & $\begin{array}{c}241 \\
99 \\
\end{array}$ & $\begin{array}{l}100 \\
100 \\
\end{array}$ & 0.742 & 0.285 \\
\hline $\begin{array}{l}\text { Carbohydrate Intake } \\
\text { - Sufficient } \\
\text { - Low }\end{array}$ & $\begin{array}{c}197 \\
13\end{array}$ & $\begin{array}{l}63.1 \\
46.4\end{array}$ & $\begin{array}{c}115 \\
15\end{array}$ & $\begin{array}{l}36.9 \\
53.6\end{array}$ & $\begin{array}{c}312 \\
28\end{array}$ & $\begin{array}{l}100 \\
100\end{array}$ & 1.977 & 0.123 \\
\hline $\begin{array}{l}\text { Protein Intake } \\
\text { - Sufficient } \\
\text { - Low }\end{array}$ & $\begin{array}{c}7 \\
203\end{array}$ & $\begin{array}{l}77.8 \\
61.3\end{array}$ & $\begin{array}{c}2 \\
128\end{array}$ & $\begin{array}{l}22.2 \\
38.7\end{array}$ & $\begin{array}{c}9 \\
331\end{array}$ & $\begin{array}{l}100 \\
100\end{array}$ & 2.207 & 0.513 \\
\hline $\begin{array}{l}\text { Fat Intake } \\
\text { - Sufficient } \\
\text { - Low }\end{array}$ & $\begin{array}{c}59 \\
151\end{array}$ & $\begin{array}{l}67.8 \\
59.7\end{array}$ & $\begin{array}{c}28 \\
102\end{array}$ & $\begin{array}{l}32.2 \\
40.3\end{array}$ & $\begin{array}{c}87 \\
253\end{array}$ & $\begin{array}{l}100 \\
100\end{array}$ & 1.423 & 0.223 \\
\hline $\begin{array}{l}\text { Fibre Intake } \\
\text { - Sufficient } \\
\text { - Low }\end{array}$ & $\begin{array}{c}4 \\
206\end{array}$ & $\begin{array}{l}44.4 \\
62.2\end{array}$ & $\begin{array}{c}5 \\
125\end{array}$ & $\begin{array}{l}55.6 \\
37.8\end{array}$ & $\begin{array}{c}9 \\
331\end{array}$ & $\begin{array}{l}100 \\
100\end{array}$ & 0.485 & 0.462 \\
\hline $\begin{array}{l}\text { Energy Intake } \\
\text { - Sufficient } \\
\text { - Low }\end{array}$ & $\begin{array}{c}149 \\
61\end{array}$ & $\begin{array}{l}61.8 \\
61.6\end{array}$ & $\begin{array}{l}92 \\
38\end{array}$ & $\begin{array}{l}38.2 \\
38.4\end{array}$ & $\begin{array}{c}241 \\
99\end{array}$ & $\begin{array}{l}100 \\
100\end{array}$ & 1.009 & 1.000 \\
\hline $\begin{array}{l}\text { Physical Activity } \\
\text { - Moderate } \\
\text { - High }\end{array}$ & $\begin{array}{c}196 \\
14 \\
\end{array}$ & $\begin{array}{l}64.1 \\
41.2 \\
\end{array}$ & $\begin{array}{c}110 \\
20 \\
\end{array}$ & $\begin{array}{l}35.9 \\
58.8\end{array}$ & $\begin{array}{c}306 \\
34 \\
\end{array}$ & $\begin{array}{l}100 \\
100 \\
\end{array}$ & 2.545 & 0.016 \\
\hline $\begin{array}{l}\text { Family Supports } \\
\text {-High } \\
\text { - Low }\end{array}$ & $\begin{array}{c}40 \\
170\end{array}$ & $\begin{array}{l}65.6 \\
60.9\end{array}$ & $\begin{array}{c}21 \\
109\end{array}$ & $\begin{array}{l}34.4 \\
39.1\end{array}$ & $\begin{array}{c}61 \\
279\end{array}$ & $\begin{array}{l}100 \\
100\end{array}$ & 1.221 & 0.596 \\
\hline
\end{tabular}

Table 3 shows that respondents with frequent consumption of vegetables and fruit are likely to have a good nutritional status. A total of 152 respondents $(67.3 \%)$ with frequent vegetable consumption and 144 respondents $(59.8 \%)$ with frequent fruit consumption had a good nutritional status. Chi-square test results obtained $p$ value 0.005, which means that there is a significant relationship between vegetable consumption habits and nutritional status.

Nutritional intake data shows that almost all respondents have sufficient carbohydrate intake, but protein, fat and fiber intake are classified as insufficient. The bivariate test results obtained $p>0.05$, which means that in this study there was no significant relationship between nutrient intake and nutritional status. 
Table 3 also shows that respondents with a minimum physical activity of 600 MET minutes/week have the opportunity to have a good nutritional status. A total of 196 respondents (64.1\%) with moderate physical activity had a good nutritional status. The results of the chi-square test in this study obtained a p value of 0.016 , which means that there is a significant relationship between physical activity variables and nutritional status.

Family support data, most of the respondents have low family support. A total of 60 respondents were categorized as high family support and had a good nutritional status (65.5\%). In this study, there was no significant relationship between family support variables and nutritional status ( $\mathrm{p} 0.596$ ).

Multivariate analysis use regression logistic was conducted to determine which variables had a dominant influence on adolescent nutritional status. The variables that can be continued in the multivariate analysis are those that have a $p$ value $<0.25$ in the bivariate test, namely vegetable consumption habits, carbohydrate intake, fat intake and physical activity. The results of multivariate analysis using logistic regression test are presented in Table 4.

Table 4 Multivariate Analysis Modeling Steps

\begin{tabular}{|l|c|c|c|c|c|c|}
\hline \multicolumn{1}{|c|}{ Variable } & OR1 & p-value1 & OR2 & p-value2 & OR3 & p-value3 \\
\hline Vegetable consumption & 1,892 & 0,008 & 1,889 & 0,008 & 1,946 & 0,005 \\
\hline Carbohydrate Intake & 1,635 & 0,230 & 1,738 & 0,175 & - & - \\
\hline Fat Intake & 1,358 & 0,259 & $-2,427$ & $-0,018$ & $-2,461$ & $-0,016$ \\
\hline Physical Activity & 2,421 & 0,018 & & & & \\
\hline
\end{tabular}

From Table 4 above, it is known that the habit of consuming vegetables ( $\mathrm{p}=$ $0.005)$ and physical activity $(p=0.016)$ are the variables that have the most influence on nutritional status, the results of the determinant analysis of the two variables are presented in Table 5 below:

Table 5 Results of Analysis of Determinants of Variable Vegetable Consumption

Habits andPhysical Activity

\begin{tabular}{|l|c|c|c|c|c|c|}
\hline \multicolumn{1}{|c|}{ Variable } & B & Wald & p-value & $\begin{array}{c}-\mathbf{2} \text { Log } \\
\text { Likelihood }\end{array}$ & $\begin{array}{c}\text { Omnibus } \\
\text { Test }\end{array}$ & $\mathbf{R}^{\mathbf{2}}$ \\
\hline Vegetables ConsumptionHabit & 0.666 & 7.879 & 0.005 & 437.888 & 0.001 & 0.057 \\
\hline Physical Activity & 0.900 & 5.830 & 0.016 & & & \\
\hline
\end{tabular}

Based on the table above, the omnibus test value shows a significance value of 0.001, which means that the addition of independent variables in the form of vegetable consumption habits and physical activity can simultaneously have a significant effect on nutritional status. The coefficient of determination $\left(\mathrm{R}^{2}\right)$ was 0.057 , indicating that the variable vegetable consumption habits and physical activity had an effect on nutritional status by $5.7 \%$. 


\section{Vegetable consumption habits and nutritional status of adolescents}

The vegetable consumption habits of adolescents aged 16-17 years in Pangkalpinang City are mostly in the frequent category ( $\geq 5$ times a week). A total of $152(67.3 \%)$ adolescents with good nutritional status have frequent consumption of vegetables and $56(49.1 \%)$ adolescents with malnutrition status have a habit of consuming vegetables that rarely. The results of the bivariate analysis obtained a $\mathrm{p}$ value of 0.005 , indicating a significant relationship between vegetable consumption habits and nutritional status.

These results are in line with research by Vazquez et al, where there is a positive correlation between the frequency of vegetable consumption and the nutritional status of adolescents. Adolescents who never eat vegetables tend to be obese compared to adolescents who consume regular vegetables (Mellin, et al., 2002).

Consumption of vegetables can reduce obesity because of their fiber content which provides a feeling of fullness so that it is thought to reduce fat and energy intake from food (Herzer, et al., 2011). Degenerative diseases such as hypertension, diabetes mellitus and coronary heart disease can be reduced by consuming vegetables and fruits. WHO recommends daily consumption of vegetables and fruit as much as $400 \mathrm{~g} /$ day as a source of fiber and to meet the needs of micronutrients. This daily requirement can be met by consuming five servings of vegetables and fruit per day.

\section{Fruit consumption habits and nutritional status of adolescents}

Inadequate eating among school-age adolescents is one of them caused by not consuming enough fruits and vegetables. Adolescents are easily influenced by their social environment such as family, school and peers (peer group) which can affect eating habits including the type of food consumed.

Most of the fruit consumption habits of adolescents aged 16-17 years in Pangkalpinang City are in the frequent category ( $\geq 5$ times a week). Data on the characteristics of the respondents 'parents also shows that the income of the respondents parents is mostly in the high category $(89.1 \%)$. However, from the results of the FFQ questionnaire, almost half of the respondents stated that fruit was not available every day at home (55\%). Only 47 respondents stated that fruit was available every day.

This can be possible due to habitual factors and access to fruit availability where there are several schools that have started providing healthy canteens under the supervision of health workers who provide fresh fruits, so that respondents are likely to consume fruit more often outside the home.

The results of the bivariate analysis obtained a p-value of 0.285 , indicating that there was no significant relationship between fruit consumption habits and nutritional status. These results are in line with research on 228 adolescents where there was no significant relationship between fruit consumption habits and nutritional status. Adolescent fruit consumption habits are influenced by many factors, such as media exposure, fruit consumption preferences and peer support, 
adolescents who lack peer support are at risk of consuming 2.4 times less fruit than $2 x$ a day. Consumption of fruit in adolescents is related to habits acquired from friends.

\section{Nutritional intake and nutritional status of adolescents}

The results showed that almost all respondents had sufficient carbohydrate intake $(91.8 \%)$, but fat intake $(74.4 \%)$, protein intake $(97.4 \%)$ and fiber intake $(97.4 \%)$ were lacking. Bivariate analysis showed that there was no relationship between energy nutrient intake $(p=1,000)$, protein $(p=0.513)$, fat intake $(p=0.223)$ and fiber intake $(p=0.462)$ with nutritional status. The results of this study are the same as research on female students in Surakarta, which shows that there is no relationship between intake of macro nutrients (protein, fat, and carbohydrates) and nutritional status. However, based on the analysis, it was found that adolescents with sufficient carbohydrate and energy intake had good nutritional status. This shows that if the intake of carbohydrates and energy is not fulfilled, there will be a greater chance of being in the malnutrition category.

\section{Physical Activity and nutritional status of adolescents}

Physical activity is a movement produced by skeletal muscles and requires energy expenditure (WHO, 2016). Mild physical activity is everything that is related to moving the body, moderate physical activity is body movement that causes a considerable amount of energy expenditure in other words, moving which causes the breath to be a little faster than usual, while strenuous activity is movement of the body that causes sufficient expenditure of energy. a lot (burning calories) so that the breath is much faster than usual ${ }^{1}$.

Based on the bivariate test, it shows that there is a significant relationship between the level of physical activity and the nutritional status of adolescents ( $p=$ 0.016). This study is in line with Weiss, which states that an increase in nutritional status is associated with a decrease in long-term physical activity, where nutritional status and physical activity have an interplay of relationships. If you do physical activity, the body will need a lot of energy, the food that is digested in the body will be converted into glucose and circulated to all parts of the target cell in order to obtain energy. When a person's physical activity is high and the energy in his body is deficient, the lipase enzyme in fat cells will break down glycerol and fatty acids and release them to target cells and the fat stores contained in the adipose tissue will be reduced.

That physical activity has an influence on the incidence of obesity. The less time spent doing moderate and strenuous activities, the greater the chance of obesity. The more activity, the more calories are used so that the body becomes normal or even thinner, but if you do not have enough activity, the body tends to store excess calories, causing excess weight.

Lack of physical activity is the fourth leading risk factor for global deaths causing an estimated 3.2 million deaths ${ }^{1}$. The decrease in physical activity is due to 
the amount of free time and sedentary behavior at work and at home. Low levels of physical activity are also caused by increased use of means of transportation ${ }^{1}$. Physical activity is one of the factors that influence nutritional status because a person's nutritional status depends on the use of nutrients consumed by doing activities. A person's physical activity can be seen from the type and intensity of the activity undertaken. Excess energy intake and not balanced with balanced energy expenditure willcause weight gain.

\section{Family Support and nutritional status of adolescents}

From the analysis, 279 (82.1\%) adolescents aged 16-18 years in Pangkal Pinang City have low family support. Only $40(65.6 \%)$ adolescents with high family support have good nutritional status. In this study, there was no relationship between family support variables and nutritional status $(\mathrm{p}=0.596)$. The results of this study are in line with the results of researchby Ardina, that there is no relationship between social support (family and friends) on nutritional status ${ }^{8}$. Family and peer support is a source of social support that can influence adolescent behavior, but does not directly affect nutritional status.

Perceptions of social support are defined as individual perceptions of the supportive behavior of people in the social environment who play an important role in a healthy lifestyle such as consumption of vegetables and fruit and maintaining a balanced diet. The results of the research found that support from friends is correlated with an increase in fruit and vegetable consumption in adolescents 7 as well as an increase in physical activity.

\section{CONCLUSION}

Adolescents who often consume vegetables and have a minimum physical activity of 600METs / day have the opportunity to have a good nutritional status, the variables of vegetable consumption habits and physical activity have an effect on nutritional status by $5.7 \%$. It is better if the school works with the parents of students and closest health workers such as the health center to provide nutrition education about balanced food and phisycal activity, so that students can change their health behavior for the better.

\section{ACKNOWLEDGEMENT}

The researcher would like to thank the principal and teaching staff of SMA in Pangkalpinang City for allowing the research on nutrition education and the students of class X, XI and XII, who had the pleasure to become research respondents.

\section{REFERENCES}

1. Ardina, R. (2016). Dukungan Sosial dan Status Gizi Remaja. Jurnal Ilmiah Kesehatan, 5(10). 
2. Emilia. (2016). Pengaruh Konseling Gizi, Aktivitas Fisik dan Asupan Makanan Terhadap Penurunan Berat Badan Remaja SMA yang Kegemukan di Kota Pangkalpinang. Tesis UNS.

3. Harista, W. (2012). Fakto-Faktor Yang Berhubungan Dengan Perilaku Pencegahan Obesitas Pada Siswi SMP Di Kota Depok. Skripsi FKM UI.

4. Herzer, M., Zeller, M. H., Rausch, J. R., \& Modi, A. C. (2011). Perceived social support and its association with obesity-specific health-related quality of life. Journal of developmental and behavioral pediatrics: JDBP, 32(3), 188.

5. Hume, C., Timperio, A., Salmon, J., Carver, A., Giles-Corti, B., \& Crawford, D. (2009). Walking and cycling to school: predictors of increases among children and adolescents. American journal of preventive medicine, 36(3), 195-200.

6. Kementrian Kesehatan RI. (2013). Riset Kesehatan Dasar. Jakarta: Badan Penelitian dan Pengembangan Kesehatan.

7. Mellin, A. E., Neumark-Sztainer, D., Story, M., Ireland, M., \& Resnick, M. D. (2002). Unhealthy behaviors and psychosocial difficulties among overweight adolescents: the potential impact of familial factors. Journal of adolescent health, 31(2), 145-153.

8. Ortega, F. B., Ruiz, J. R., Castillo, M. J., \& Sjöström, M. (2008). Physical fitness in childhood and adolescence: a powerful marker of health. International journal of obesity, 32(1), 1-11.

9. Wang, Y., \& Lobstein, T. I. M. (2006). Worldwide trends in childhood overweight and obesity. International journal of pediatric obesity, 1(1), 11-25.

10. World Health Organization. (2016). World health statistics 2016: monitoring health for the SDGs sustainable development goals. World Health Organization. 